\title{
A STUDY ON SOIL EROSION AND ITS IMPACTS ON FLOODS AND SEDIMENTATION
}

\author{
H. Mahabaleshwara ${ }^{1}$, H.M. Nagabhushan ${ }^{2}$ \\ ${ }^{1}$ Professor \& Former Principal, R.Y.M Engineering College, Bellary \\ ${ }^{2}$ Professor \& Dean, R.Y.M Engineering College, Bellary
}

\begin{abstract}
Balanced ecosystem comprising of soil, water and plant environment is essential for survival and welfare of the mankind. However, eco-system of the earth has been disturbed in the past due to over exploration of the nature for meeting the demands generated due industrial growth etc. Activities such as deforestation, Mining, Agriculture etc., that dominantly occurred in the recent past due to developments resulted in soil on land surfaces exposed directly to the rains. This unprotected soil could be easily removed from the land surfaces by the combined action of rain and the resulting flow. Vast tracts of land have been thus irreversibly converted into infertile surfaces due to the continued soil erosion. These degraded land surfaces also become sources of pollution to the natural water. Soil eroded from the upland areas of the catchment, gets deposited in the rivers causing aggradation. This causes increase in floods plain area of the river choking of the clearance below the bridge and culverts etc. Reservoir sedimentation is the problem of prime concerns for water resources engineers and gets accelerated due to catchment soil erosion. The net amount eroded soil (sediment) reaching to the catchment outlet over a period of time is termed as sediment yield. For the project planning purpose estimates of sediment yield can be made with the available techniques by using the data on the hydrometeorology and the catchment characteristics.
\end{abstract}

The tools of Remote sensing (RS) and Geographical Information Systems (GIS) are vigorously being utilized to give a Digital representation of the hydrological variables like soil erosion. For soil conservation planning however it is necessary to estimate the variation of soil erosion and sediment yield with the time during storm events or for a series of storm events. The problem of soil erosion is prevalent over about $53 \%$ of the total land $\left(1750000 \mathrm{~km}^{2}\right.$ out of the total land area of $\left.3280000 \mathrm{~km}^{2}\right)$ area of India (Narayana \& Ram Babu, 1983).The regions of high erosion include the severely eroded gullied land along the banks of the river Yamuna, Chambal and Mahi and other west flowing rivers in Western Indian states. The Himalayan and lower Himalayan regions have been greatly affected by soil erosion due to intensive deforestation, large scale road construction, mining and cultivation on steep slopes. Areas affected by soil erosion in India can be broadly grouped into two categories, representing, firstly the Himalayan and Lower Himalayan region and secondly other regions. In the present paper light is focused on erosion and its impacts on sedimentation and Floods considering relevant case studies, also some of the potential remedial measures are briefly discussed.

Keywords: Deforestation, Geographical Information system, Soil Erosion, Reservoir Sedimentation, Mining and cultivation. ****

\section{INTRODUCTION}

Erosion of soil from the catchments involves the process of detachment of soil from the soil surface and its transport by rainfall and runoff [1]. Water from a raindrop acts both as a wetting source and as an energy source causing detachment. The shear strength of soil decreases with increasing wetness. The overland flow exerts shear stress on the surface thereby inducing both detachment and transportation of soil particles. Deposition of detached material takes place when the transport capacity of flow is smaller than the quantity of material being transported. The problem of soil erosion is prevalent over about $53 \%$ of the total land $\left(1750000 \mathrm{~km}^{2}\right.$ out of the total land area of $3280000 \mathrm{~km}^{2}$ ) area of India (Narayana \& Ram Babu, 1983). Activities such as deforestation, Mining, Agriculture etc that dominantly occurred in the recent past due to developments, resulted in soil on land surfaces exposed directly to the rains. This unprotected soil could be easily removed from the land surfaces by the combined action of rain and the resulting flow. Vast tracts of land have been thus irreversibly converted into infertile surfaces due to the continued soil erosion. Accelerated soil erosion by water or wind may affect both, agricultural areas and the natural environment, and is one of the most widespread of today's environmental problem. It has impacts which are both on-site (at the place where the soil is detached) and off-site (where the eroded soil ends up).The GLASOD study estimated that around $15 \%$ of the Earth's ice-free land surface is afflicted by all forms of land degradation. Of this, accelerated soil erosion 
by water is responsible for about $56 \%$ and wind erosion is responsible for about $28 \%$. This means that the area affected by water erosion is roughly around 11 million square $\mathrm{km}$, and the area affected by wind erosion is around 5.5 million square $\mathrm{km}$.

Most of the rivers in India rise in hills, flows towards plain after traversing certain distance and continue towards outfall into sea or other river. It is known that change in river bed and/or bank takes place due to imbalance in supply and transport capacity of sediment that varies as power of flow velocity. Further changes in the river bed also take place if the soils forming banks are weaker against the erosive actions of flow velocity. Protection is required at such location for safety of adjoining villages, fields and establishment. The process of deriving such measures starts from identification of erosion area that can be carried out through analysis of bank line data collected from satellite. The findings are to be confirmed through ground truth verification .Design parameters for deriving protection works were estimated through simulation or on site measurements.

Landslides are the other dominant cause of soil erosion and related problems in the Himalayas. Fig 1 shows locations of landslide prone areas of India (Garde and Kothyari , 1989) . This figure indicates that in India landslides mainly occur along the Shiwaliks in the Himalayas. An intense thunderstorm over the Alaknanda valley in the Himalayas during 1970 led to severe erosion and breached the barriers which had developed across the Alaknanda River and its tributaries. The sediment load thus increased enormously also the concentration of sediment in the Ganga River at Hardwar. The net amount eroded soil (sediment) reaching to the catchment outlet over a period of time is termed as sediment yield. Reservoir sedimentation is the problem of prime concerns for water resources engineers and gets accelerated due to catchment soil erosion. Soil eroded from the upland areas of the catchment, gets deposited in the rivers causing aggradation thereby the normal flow path in the river course gets congested. This causes increase in floods plain area of the river, choking of the clearance below the bridge and culverts etc. Fig 2 shows erosion rates in India. The sediment incoming from the upper reach could not be transported further on account of lower velocities. It was observed that along the stretch of the river, sediment deposition or erosion take place due to imbalance between sediment inflow and sediment transport capacity.

\section{TYPES OF SOIL EROSION}

\subsection{Inter-Rill Erosion}

In the inter-rill area of catchment, the soil detachment is caused by the impact of raindrops. . The detached soil particles are transported to the rill system by slash and also to a small extent by overland flow. In this process, the water and sediment are transported over small distance on the surface with small flow depth and without formation of elementary channel called rills. Once the rills are formed, flow is concentrated and erosion is related to other characteristics. Sheet erosion is synonymous to inter-rill erosion and can be termed as uniform removal of soil without development of conspicuous water channels.

\subsection{Rill Erosion}

Rainfall may also move soil indirectly, by means of runoff in rills (small channels) or gullies (larger channels, too big to be removed by tillage). In many parts of the world, rill and gully erosion is the dominant form of water erosion. Rills are elementary small channels in the upland portion of the catchment. Rills are not permanent features: rills formed by one storm can be obliterated before next storm occurs. Most rill systems are discontinuous which means that they have no direct connections with the main stream. Rills ace usually initiated at the critical distance where overland flow gets channelized. Relative importance of rill erosion depends on the rill spacing. Larger is the spacing between the rills, greater will be the rill erosion. Rill erosion accounts for majority of erosion from the hill side.

\subsection{Gully Erosion}

Gullies are steep sided water channels which carry ephemeral flows during storms. Gullies are associated with accelerated erosion and hence with landscape instability. Gullies are not normally developed from the rills. The development of gullies is a complex process which has not fully understood.

\subsection{Channel Erosion}

It includes the stream bed and stream bank erosion and the flood plain scour. Deposition occurs in channels when the quantity of detached soil coming from the inter-rill, rill and gully erosion exceeds its transport capacity.

\subsection{Sheet Erosion}

It is the movement of soil from raindrop splash and runoff water. It typically occurs evenly over a uniform slope and goes unnoticed until most of the productive soil topsoil has been lost. Deposition of eroded soil occurs at the bottom of the slope in low areas.

\subsection{Bank erosion}

Natural streams and constructed drainage channels act as outlets for surface water runoff and subsurface drainage systems. Bank erosion is the progressive undercutting, scouring and slumping of these drainage ways. Poor construction practices, inadequate maintenance, uncontrolled livestock access and cropping too close can all lead to bank erosion problems. The direct damages from bank erosion include loss of productive farmland, undermining of structures such as bridges, increased need to clean out and maintain 
drainage channels and washing out of lanes, roads and fence rows. Fig 4 shows bank erosion in undercutting and scouring.

In general sheet erosion is the prime cause of erosion in humid areas whereas, in more arid areas where rainfall is experienced in short high intensity storms, channel erosion in more predominant. Material derived from sheet erosion is usually fine and carried in suspension to and through the channel system. Channel erosion produces coarser material.

\section{FACTORS AFFECTING SOIL EROSION AND SEDIMENT YIELD}

The quantity of sediment generated within a catchment depends upon several factors related to Hydro-meteorology, Topography, Land use and Lithology.

\subsection{Climate}

The climate has always been observed to have a strong influence on soil erosion and sediment yield. Larger the raindrop size and greater the rainfall intensity more the soil splash in inter-rills. The presence of overland flow increases the discharge capacity and splash capacity of the raindrops. The temperature plays an important role in the process of weathering which leads to disintegration of rocks. Rate of soil erosion and sediment yield is found to increase if the precipitation is concentrated during one season instead of being nearly uniformly distributed over the year.

\subsection{Topography}

Catchment area, relief and drainage density are some of the factors related to catchment topography which are found to influence sediment yield. Velocity of overland flow and hence the shear stress on the land surface and transport capacity are more responsible for erosion. The erosion rate per unit catchment area is expressed by many, as proportional to (slope)m (length)n. Values of $\mathrm{m}$ are found to vary between 1.30 to 2.00 while $\mathrm{n}$ is found to vary between 0.30 to 0.70 in the case of erosion by overland flow.

\subsection{Land Use}

Effects of land use on sediment yield are closely linked to those of climate, geology and soil characteristics. Vegetation or plant cover reduces the soil erosion, its effectiveness depending upon the height and continuity of canopy, density of ground cover and root density. Roots play an important role in reducing erosion rate by binding the soil mass to increase its resistance to flow. Generally forests are most effective in reducing erosion because of their canopy; dense grass is equally effective.

\subsection{Geology}

The interdependence among climate, land use and soil/geology makes it difficult to detect the specific role played by soil and geology on sediment yield production. It understood that geologic conditions indirectly influence the vegetation and therefore its effect is indirectly included if vegetation cover is taken as one of the factors affecting soil erosion and sediment yield.

\section{MATHEMATICAL MODELLING OF SOIL EROSION AND SEDIMENT YIELD PROCESSES}

Regional estimation of soil erosion is needed for planning and the design of soil conservation measures (Walling, 1988). Such estimates can be obtained through actual measurements and also through the use of estimation procedures. Surveys for determination of soil erosion rates from catchments and deposition rates in reservoirs are frequently conducted by the various Govt agencies in India (ICAR, 1984 and CBIP, 1981). Estimation procedure can be therefore used to estimate erosion rates for such catchments.[2]

The Universal Soil Loss Equation (USLE) (Wischmeier \& Smith, 1978) has been used for estimation of on-site erosion rates.

$$
\begin{aligned}
& \mathrm{S}_{\mathrm{am}}=\mathrm{CP} 0.6^{\mathrm{Fe} 1.7} \mathrm{~S}^{0.25} \mathrm{D}_{\mathrm{d}}^{0.10}\left(\mathrm{P}_{\max } / \mathrm{P}\right) 0.19 \\
& \mathrm{~F}_{\mathrm{e}}=\left(0.8 \mathrm{~F}_{\mathrm{A}}+0.6 \mathrm{~F}_{\mathrm{G}}+0.3 \mathrm{~F}_{\mathrm{F}}+0.1 \mathrm{~F}_{\mathrm{W}} / \mathrm{A}\right.
\end{aligned}
$$

Where

$\mathrm{S}_{\mathrm{am}}=$ Mean annual sediment yield in $\mathrm{cm}$

$\mathrm{C}=$ Coefficient depending on the geographical location of the catchment

$\mathrm{P}=$ Average annual rainfall in $\mathrm{cm}$,

$\mathrm{A}=$ Catchment area in $\mathrm{km}^{2}$

$\mathrm{S}=$ Land slope

$D_{d}=$ Drainage density in $\mathrm{km} / \mathrm{km}^{2}$

$\mathrm{P}_{\max }=$ Average max monthly rainfall in $\mathrm{cm}$

$\mathrm{F}_{\mathrm{e}}=$ Erosion factor

$\mathrm{F}_{\mathrm{A}}=$ Area of arable land in the catchment

$\mathrm{F}_{\mathrm{G}}=$ Area occupied by the grass and scrub

$\mathrm{F}_{\mathrm{W}}=$ Area of waste land

$\mathrm{F}_{\mathrm{F}}=$ Forested area

Efforts to mathematically predict soil erosion due to flow of water were initiated about five to six decades ago. Transport of eroded sediment to downstream areas is governed by relationships for transport capacity. When the soil or sediment particles are detached from the ground surface they become part of the flow and can be transported $\mathrm{d} / \mathrm{s}$ to distances varying from a few millimeters to many kilometers.

Equation of continuity for sediment detachment and transport is the governing equation for describing the soil erosion 
process. As per Foster and Mayer, (1972) and Bennett, (1974) the equation is described as below.

$$
\delta \mathrm{q}_{\mathrm{s}} / \delta \mathrm{x}+\rho_{\mathrm{s}} \delta\left(\mathrm{C}_{\mathrm{S}} \mathrm{h}\right) / \delta \mathrm{t}=\mathrm{D}_{\mathrm{l}}+\mathrm{D}_{\mathrm{R}}
$$

Where

$\mathrm{q}_{\mathrm{s}}=$ sediment discharge

$\rho_{\mathrm{s}}=$ Mass Density of the sediment particles

$\mathrm{C}_{S}=$ Concentration of the sediment being transported

$\mathrm{D}_{\mathrm{R}}=$ Detachment by flow

$\mathrm{D}_{1}=$ Detachment by raindrop impact

$\delta \mathrm{q}_{\mathrm{s}} / \delta \mathrm{x}=$ Loss of sediment load with distance

$\rho_{\mathrm{s}} \delta\left(\mathrm{C}_{\mathrm{S}} \mathrm{h}\right) / \delta \mathrm{t}=$ Storage rate of sediment within the flow depth

For shallow and gradually varied flows, the storage term $\rho_{\mathrm{s}} \delta$ $\left(\mathrm{C}_{\mathrm{S}} \mathrm{h}\right) / \delta \mathrm{t}$ can be neglected, resulting in the steady continuity equation which is used more widely (Curtis , 1976 : Foster and Huggins , 1977)

$$
\delta \mathrm{q}_{\mathrm{s}} / \delta \mathrm{x}=\mathrm{D}_{\mathrm{l}}+\mathrm{D}_{\mathrm{R}}
$$

\section{MEASURES TO CONTROL EROSION AND ITS DEPOSITION}

The general problem due to soil erosion and deposition are worldwide problems and not restricted to India. However for sustainable development it will be essential to thoroughly understand and solve these problems.[6]

Following are some of controlling measures of erosion and deposition of silt in Reservoirs and water courses.

1. Implementation of soil conservation methods.

2. Construction of upstream sediment traps and by evolving effective procedures for sediment routing and sediment removal from existing reservoirs.

3. Contour farming by planting along slope of a hill, following the natural contours of the land. Wind erosion can be controlled by planting a windbreak. A windbreak can be a row of trees, bushes etc

4. Preventing deforestation and adopting practice of Afforestation.

5. Controlled practice of mining and taking care for balancing the ecological system.

6. Operating the silt sluices frequently and disposing the accumulated silt from the reservoirs.

7. Practicing for construction of bunds along the erosion prone area and desilting the deposited material.

\section{IMPACTS DUE TO SOIL EROSION}

The impacts due to soil erosion depends on the intensity of erosion, location of settlement of eroded material, form of eroded sediment yield etc,. The important adverse effects are

\subsection{Impacts of Erosion on Soil Quality}

It is known that top soil of the Earth's surface is only a fertile one containing organic matter of small fraction ( $2 \%$ to $4 \%$ ) of soil surface and it contributes to productivity through its effect on the physical, chemical and biological properties of the soil to support for plant growth, if this soil gets eroded due to erosion there will be a serious impact on healthy growth of plants.

\subsection{Impacts of Erosion on Air Quality}

Soil particles blown by the wind into the air have a major impact on human and animal health. Particles suspended in air by wind are easily inhaled and accumulate in lung tissues causing major respiratory.

\subsection{Impacts of Erosion on Water Quality}

Sediment deposition in lakes and rivers increases water turbidity making it difficult for light to penetrate the water. This causes problems for aquatic plants that need sunlight for photosynthesis. Sediments are also rich in nutrients such as phosphorus and nitrogen. These promote the excessive growth of algae. Deplete oxygen in the water resulting in the death of aquatic animals from lack of oxygen.

\subsection{Impacts on Reservoir Sedimentation}

The soil eroded and transported from headwater catchment can be deposited at downstream points in the river, causing many problems. The sedimentation of reservoirs[3] continues to remain the important problem resulting from soil erosion in catchments. About 126 dams which are $30 \mathrm{~m}$ or more in height had been completed in India for irrigation, Hydropower generation, flood control etc., before the year 1971. Many of these dams now contain significant accumulation of sediment eroded from their catchments. Analysis of the sedimentation data indicates a wide range of sedimentation rates in these reservoirs. Few reservoirs in India have lost as much as $50 \%$ of their capacity to date. Fig 3 indicates loss in the storage capacity of Indian reservoirs. Following table shows reservoir sedimentation rates in India

Table-1: Reservoir sedimentation rates in India (based on Morris, 1995)

\begin{tabular}{|l|l|l|l|l|l|l|}
\hline Reservoir & $\begin{array}{l}\text { Year of } \\
\text { construction }\end{array}$ & $\begin{array}{l}\text { Catchment } \\
\text { area(km2) }\end{array}$ & $\begin{array}{l}\text { Reservoir } \\
\text { volume } \\
\text { (TMCft) }\end{array}$ & $\begin{array}{l}\text { Sedimentation } \\
\text { rate } \\
\text { (TMCft)/ year }\end{array}$ & $\begin{array}{l}\text { 50\% } \\
\text { (apacity } \\
\text { lost year }\end{array}$ & $\begin{array}{l}\text { Life of } \\
\text { reservoir } \\
\text { (years) }\end{array}$ \\
\hline Sriramsagar & 1970 & 91750 & 35 & 0.62 & 1998 & 56 \\
\hline Nijamsagar & 1930 & 21694 & 39 & 0.64 & 1960 & 61 \\
\hline Matatila & 1956 & 20720 & 55 & 0.44 & 2018 & 124 \\
\hline
\end{tabular}




\begin{tabular}{|l|l|l|l|l|l|l|}
\hline Hirakud & 1956 & 83395 & 97 & 0.66 & 2030 & 147 \\
\hline Girna & 1965 & 4729 & 129 & 0.80 & 2045 & 161 \\
\hline Tungabhadra & 1953 & 28179 & 133 & 1.01 & 2019 & 132 \\
\hline Pnchet Hill & 1956 & 10966 & 137 & 1.05 & 2021 & 130 \\
\hline Bhakra & 1958 & 56980 & 172 & 0.60 & 2101 & 287 \\
\hline Maithon & 1955 & 6294 & 218 & 1.43 & 2031 & 152 \\
\hline $\begin{array}{l}\text { Lower } \\
\text { Bhavani }\end{array}$ & 1953 & 4200 & 222 & 0.44 & 2205 & 504 \\
\hline Mayurakshi & 1954 & 1860 & 327 & 1.63 & 2054 & 201 \\
\hline Gandhisagar & 1960 & 23025 & 336 & 0.96 & 2135 & 350 \\
\hline
\end{tabular}

Reservoirs are the life line components for the overall development of a country, sufficient number of small, medium and large scale reservoirs proves effective water resources management of a country thereby protecting the country from the probable floods and droughts. Sedimentation is major problem in the operation and maintenance of reservoirs which greatly affects over the capacity of the reservoir and the useful life of the reservoir decreases. The impacts due to sedimentation has the adverse effects on designed live storage which directly results on proposed purposes causing greater economic loss also chances for flooding situation at downstream. So the prediction of probable rate of silting of reservoirs is an important tool for a hydrologist in the planning and designing of reservoirs also estimating the deposited silt. Presently in India many reservoirs are facing the problem of sedimentation resulting reduction in the capacity to about 0.5 $\%$ to $1.20 \%$ every year, thus it is inevitable to release excess inflow during monsoon which flow as unused at $\mathrm{d} / \mathrm{s}$ reaching nearby sea or ocean resulting greater loss in water wealth. Hence it is the need of the hour to study on origin of silt, transportation, deposition patterns, and its impacts also remedial measures to arrest the silt erosion and desilting methods. It is difficult to built new reservoirs but it is possible to restore the capacity. [7]

Reservoir sedimentation is the process of accumulation of silt carried by the flowing river water at the different zones of the reservoir base causing reduction of reservoir capacity. The rate of sediment deposition is monitored by periodical hydrographic survey. If the sedimentation continues for a longer periods, a stage likely to reach when the whole reservoir may get silted up and becomes useless. Every river carries certain amount of sediment load; it tries to settle down at river bottom due to gravitational force, but may be kept in suspension due to upward current in the turbulent flow which may overcome the gravity force. Silt carried along the river bed is called bed load which is coarser and carried along the flow in the suspension form called as suspended load which is fine silt.

The impacts due to sedimentation causing degradation in social and economical status of its dependents. It is imperative to ensure that realistic assumptions about the rate of sedimentation are made at the planning stage so that the continued optimum benefits are derived and remedial measures are taken to minimize sediment deposition and to prolong the useful life of reservoirs.

It is unfortunate that many of Indian reservoirs are suffering from the decease of sedimentation, the study or investigation shows ignorance about catchment treatment; silt arresting structures, desilting etc. Once if the reservoirs are filled with abnormal amount of silt it is difficult to remove or to restore its capacity by increasing its height or construction of parallel reservoirs, hence it is more advisable to control at its origin and prevent/minimize its entry by adopting suitable measures. Present requirement is not the construction of big reservoirs but the effective management of existing dams regarding these, experts are timely cautioning the Govt to initiate immediately about the issue.

Tungabhadra Dam is one of the major reservoirs in Karnataka built across the river Tungabhadra blessing the farmers of both Karnataka (partly) and Andhra Pradesh (partly) is severely affected with sedimentation by losing about $30 \mathrm{TMCmt}$ of water out of its gross capacity is considered as case study.

Table-2: Rate of sedimentation in severe seven reservoirs of Karnataka

\begin{tabular}{|l|l|l|l|l|l|}
\hline $\begin{array}{l}\text { Sl } \\
\text { no }\end{array}$ & $\begin{array}{l}\text { Name of the } \\
\text { reservoir }\end{array}$ & $\begin{array}{l}\text { Loss in the capacity } \\
\text { (TMCft) }\end{array}$ & $\begin{array}{l}\text { Gross storage } \\
\text { capacity (TMCft) }\end{array}$ & $\begin{array}{l}\text { Latest Gross storage } \\
\text { (TMCft) }\end{array}$ & $\begin{array}{l}\text { Rate } \\
\text { siltation/year }\end{array}$ \\
\hline 1 & Tungabhadra & 28.131 & 132.473 & 104.341 & 0.55 \\
\hline 2 & Malaprabha & 2.775 & 43.778 & 41.004 & 0.277 \\
\hline 3 & Bhadra & 2.152 & 71.535 & 69.392 & 0.051 \\
\hline 4 & Krishanaraja sagar & 1.054 & 48.665 & 47.611 & 0.018 \\
\hline
\end{tabular}




\begin{tabular}{|l|l|l|l|l|l|}
\hline 5 & Narayanpur & 10.155 & 37.842 & 27.685 & 0.406 \\
\hline 6 & Almatti & 5.309 & 123.108 & 117.799 & 0.408 \\
\hline 7 & Hipparagi & 0.126 & 3.522 & 3.396 & 0.014 \\
\hline
\end{tabular}

\subsubsection{Causes for Sedimentation}

Erosion of silt particles is the main cause for sedimentation. The sediment inflow rate into a particular reservoir is, in general, a function of the watershed characteristics such as drainage area, average land and channel slope, soil type, land management and use, and hydrology. The ratio of the volume of sediment trapped in a reservoir to the volume of incoming sediment is usually referred to as the reservoir trap efficiency.

Main factors responsible for the sedimentation are:

1. Physical and Hydrological characters of the catchment, Deforestation.

2. Intensity of erosion in the catchment (sheet, rill, gully and stream channel erosion).

3. Quality, quantity and concentration of the sediment brought down by the river.

4. Over exploitation of minerals in the catchment and Trap efficiency of the reservoir.

5. Size, shape and length of the reservoir

6. Method of reservoir operation

7. Exposure of deposited material.

8. Land use pattern and cultivation at the head of the reservoir.

\subsubsection{Estimation of Erosion}

The amount of sediment inflow to a reservoir depends on the sediment yield produced by the upstream watershed. Universal soil loss equation (USLE) is used to compute the soil loss.[4][5]

$$
\mathrm{A}=\mathrm{R} \text { K L S C P }
$$

Where

A = computed soil loss in tons/acre/year

$\mathrm{R}=$ Rainfall factor

$\mathrm{K}=$ soil erodibility factor

$\mathrm{L}=$ slope length factor

$\mathrm{S}=$ slope steepness factor

$\mathrm{P}=$ Erosion control practice factor

\subsubsection{Methods of Measurements of Sedimentation}

Measurement of reservoir sedimentation is an important is an important aspect to know the exact rate of sedimentation and to take suitable measures to combat it also helps to compare with the assumed rate of sedimentation at the time of design.

Following are the methods adopted

1. Inflow outflow method or sediment transport method
2. Capacity survey methods.

3. Remote sensing and GIS,GPS

\subsubsection{Inflow Outflow Method}

It is an indirect method of measurement of sedimentation. In this the incoming and outgoing sediment load is worked out on the basis of observations of discharge and suspended sediment samples taken at the $\mathrm{u} / \mathrm{s}$ and $\mathrm{d} / \mathrm{s}$ of reservoir. The amount of sediment deposited $\mathrm{Q}_{\mathrm{td}}$ in the reservoir during any given period can be computed by

$$
\mathrm{Q}_{\mathrm{td}}=\mathrm{Qti}-\left(\mathrm{Q}_{\mathrm{to}}+\mathrm{Q}_{\mathrm{ts}}\right)
$$

Where

Qti $=$ Sediment inflow

$\mathrm{Q}_{\text {to }}=$ Sediment outflow

$\mathrm{Q}_{\mathrm{ts}}=$ Change in the amount of sediment held in suspension in stored water during the same time interval.

\subsubsection{Capacity Survey Methods}

Surveys of existing reservoirs for determining loss of storage space and distribution of sediment deposits within the reservoir provides data on sediment yield rate as well as for operation purpose.

Methods:

1. Contour method (Photographic survey or Bathymetric survey)

2. Range line method (Hydrographic survey with echo sounding equipment)

\subsubsection{A Case Study of Tungabhadra Reservoir (Karnataka)}

Tungabhadra Reservoir[8] is multipurpose river valley project built across the river Tungabhadra near Hospet, Bellary Dist, Karnataka. Tungabhadra reservoir is the life line of both Karnataka and Andhra Pradesh which caters the needs for the Irrigation, Power Generation, Domestic, and Industries etc. This reservoir is severely affected by the sedimentation, as per the recent studies a total of about $30.00 \mathrm{TMCft}$ of storage capacity is lost due to the deposition of silt 
Table-3: Salient Features of TB Dam

\begin{tabular}{|l|l|}
\hline Catchment Area & 28179.00 Sq Km \\
\hline Type of Dam & Gravity Dam with 32 spillways \\
\hline Length of the Dam & $2449.00 \mathrm{~m}$ \\
\hline Height of the Dam & $35.36 \mathrm{~m}, \mathrm{MRL}:+497.74 \mathrm{M}$ \\
\hline Gross Storage & $133.00 \mathrm{TMCft}$ \\
\hline Live Storage & $130.70 \mathrm{TMCft}$ \\
\hline Dead Storage & 2.30 TMC ft \\
\hline Year of first impounding & 1953 A.D. \\
\hline Water spread area & 380.00 Sq Km \\
\hline Total command area & 5.12 Lakh Ha \\
\hline
\end{tabular}

Due to the good rainfall in the catchment area, the water flow from the TB Reservoir this year has observed more than 211 TMCft, and it is for the first time in five years the outflow from the reservoir has breached the 200 TMCft mark, this is due to loss in the storage due to silting.

Following measures are recommended:

1. Construction of balancing reservoirs.

2. Restoration of existing old tanks and filling through canals.

3. Diversion of water from the reservoir by interlinking of all tanks and enhancing the capacity of tanks.

4. Construction of parallel canal at both left and right banks for utilizing surplus flow.

5. Diversion of Tungabhadra river water at the $\mathrm{u} / \mathrm{s}$ of Dam during flood periods into neighbouring water courses.

\subsection{Impacts on Floods}

Floods are the natural calamity which results in huge losses in the human lives and the property. In India occurrence of floods are very frequent, many existing example proves its severity. A flood is relatively high stream flow that overtops the natural or artificial banks in any reach of a stream. The overtopping of the banks results in spreading of water flow, the flood plains and generally comes into conflicts with men and his activities. Usually no overflow of the banks during high discharges and the problem is confined to bank erosion, rise of bed level due to sedimentation. Occurrence of floods due to excessive precipitation, combined with inadequate channel capacity. Over spilling can also occur due to obstruction in or aggradation of the river bed.

Erosion leads for carrying of silt along with river water, part of which gets accumulated at the bed also along the banks, thereby rise in the bed level and congestion in the water flow will occur. The erosion of soil due to cultivation practices in the encroached river course results to flooding situation.

\subsubsection{Measures to control floods}

1. Sound watershed management through extensive soil conservation, catchment area treatment, preservation of forests and increasing the forest area and construction of check dams.

2. Desilting at the selected zones along the river course.

3. Protecting the original river course without any habitation and cultivation.

4. Study of silt concentration and its accumulation phenomenon.

5. Monitoring the bed levels, width of river, alignment of course and acting for restoration to possible extent.

6. Adequate flood cushion to be provided in the storage structures.

\subsubsection{Uttarakand Flood Tragedy (on June 16 and 17, 2013)}

It is the recent massive natural disaster killed thousands of human lives and destroyed huge valuable assets. This flood is due to combined effect of intensive rainfall, land slide also due to manmade natural destruction. Erosion of soil intensified for more casualities because of more than 3- 4 meters of soil deposition, many persons are buried in the soil. Total loss estimated is about 3000 crores. Uttarakanda must be declared as eco-sensitive zone said Jayanthi Natarajan, Union Minister for Environment and Forest.As per the experts due to the high rate and congested growth in the valleys of Kedaranath and Badrinath by cutting the forest and hills which was suppose to be the path of rivers in the past.About 200 villages surrounding the Kedaranath and total of 2500 villages in the state are washed away due to flash floods and in addition to the tourist and Pilgrims many locals are also lost their lives. The disaster occurred in the Himalayan region is it manmade? or made by nature ? Or due to Global warming, many of Environmental and Science experts are criticized that it is manmade due to erratic construction of Roads, Hydro Electrical Power plants, cutting of the hillocks but it is not due to cloud bursting. Since 30 years without any control the state Govt Uttarakanda had made abnormal development destroying the environment. Use of huge amount of explosives, destroying the forest made the region unstable.

The Himalayan mountain are consists of unstabilized soil apart this human being are made many roads and developmental activities there by disturbing the soil which leads for the landslides and erosion of soil adjacent to the river during excess flow. The original paths of the river were deviated due to construction of the various projects. Huge amount of silt deposition made to occur more floods. The natural disaster is due to neglecting the Geology , Geographical features, topographical characteristics of the Himalayan region abnormal development of the Holy places, 
expanding tourism activities, multistoried buildings, Hotels very adjacent of the rivers encroaching the river water path. More than 70 Hydro power plants already existing along the river course, the natural river course changed and many tunnels are drilled, huge cut of hills made disturbance in the age old flow path of the rivers. Erratic encroachment of the river basin and uncontrolled development of urbanization, huge building etc made to occur this incident told by the Environmentalist. Complete destruction of the entire forest encouraged for the flood seriousness.

\section{CONCLUSIONS}

Erosion of soil from the catchments involves the process of detachment of soil from the soil surface and its transport by rainfall and runoff. Deposition of detached material takes place when the transport capacity of flow is smaller than the quantity of material being transported. The impacts due to erosion have severe effects on the reservoir sedimentation and to certain extent on floods. The main cause for the erosion is due to deforestation, lithological characteristics of the soil of particular area, improper treatment of catchment and other anthropogenic activities etc. Hence it is concluded that suitable erosion controlling measures are to be implemented for preventing further negative impacts so that reservoirs can be maintained with their storage capacity and damages due to floods can be minimized.

\section{REFERENCES}

[1]. River behavior Management and Training : Vol-1, Publication No 204, Central Board of Irrigation and Power, New Delhi, 1989.

[2]. Erosion and Sediment yield : Hydrology Journal, Indian Association of Hydrologists (IAH), ISSN 0971-569X, IAHS Publication No.236, 1996.

[3]. Sedimentations in Reservoirs - CBIP, Technical Report20, Volume -I, September 1997

[4]. Bhaskar J.Das , S.K.Singal \& Ranvir Singh : Estimation of Erosion in an Ungauged Wetland Catchment, Hydrology Journal, Indian Association of Hydrologists (IAH), ISSN 0971-569X, Volume 31, No 1-2, Jan-June 2008

[5]. U.C.Kothyari: Soil Erosion and Sediment Yield Modelling, The Indian Society for Hydraulics Journal , Hydraulic Engineering (ISH Journal) ISSN-0971-5010, Vol 14 No.1, Mar-2008.

[6]. V.G.Bhave and R.A.Oak: Protection Measures for Erosion Area in Goutami Godavari River ,The Indian Society for Hydraulics Journal, Hydraulic Engineering (ISH Journal) ISSN-0971-5010, Vol 17 No.1, Mar-2011.

[7]. Review of Sediment Control Measures in Reservoirs Indian water week 2012 - Water, Energy and Food Security; call for solution 2012, New Delhi.

[8]. Report of Sedimentation studies of Tungabhadra Reservoir: Karnataka Engineering Research station, Hydraulic division, Krishnarajasagar Reservoir Dam site 


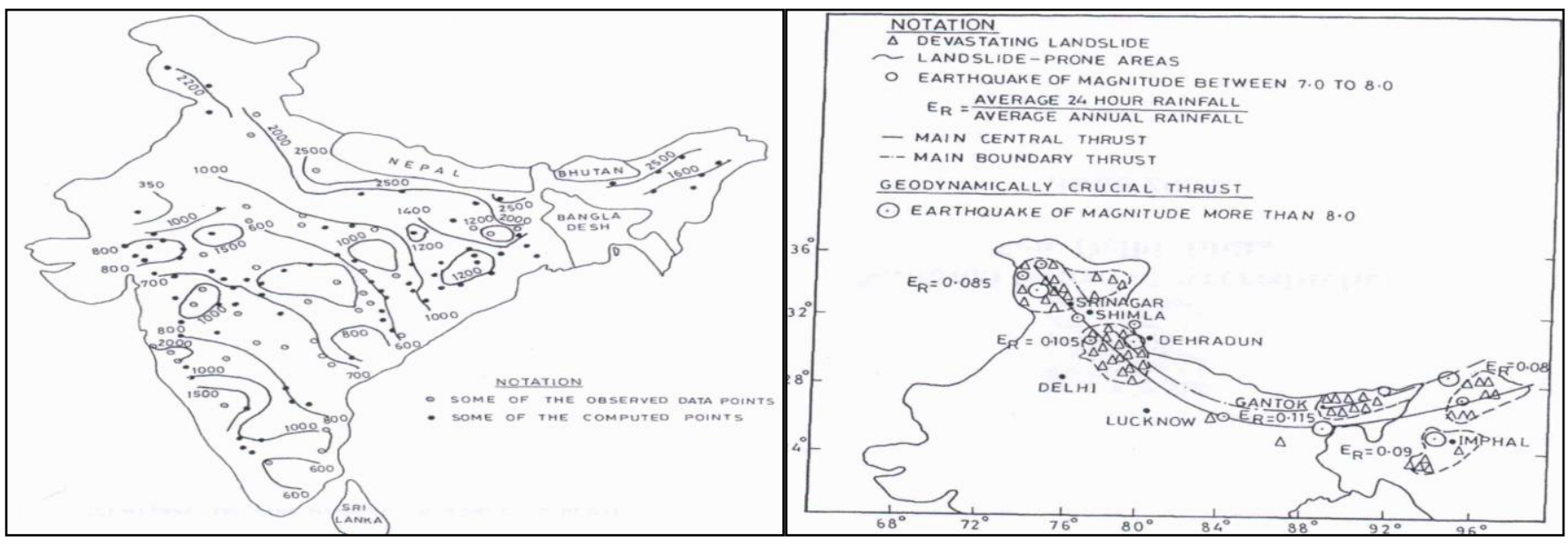

Fig-1: Landslide prone areas of India

Fig - 2: Erosion rates in India
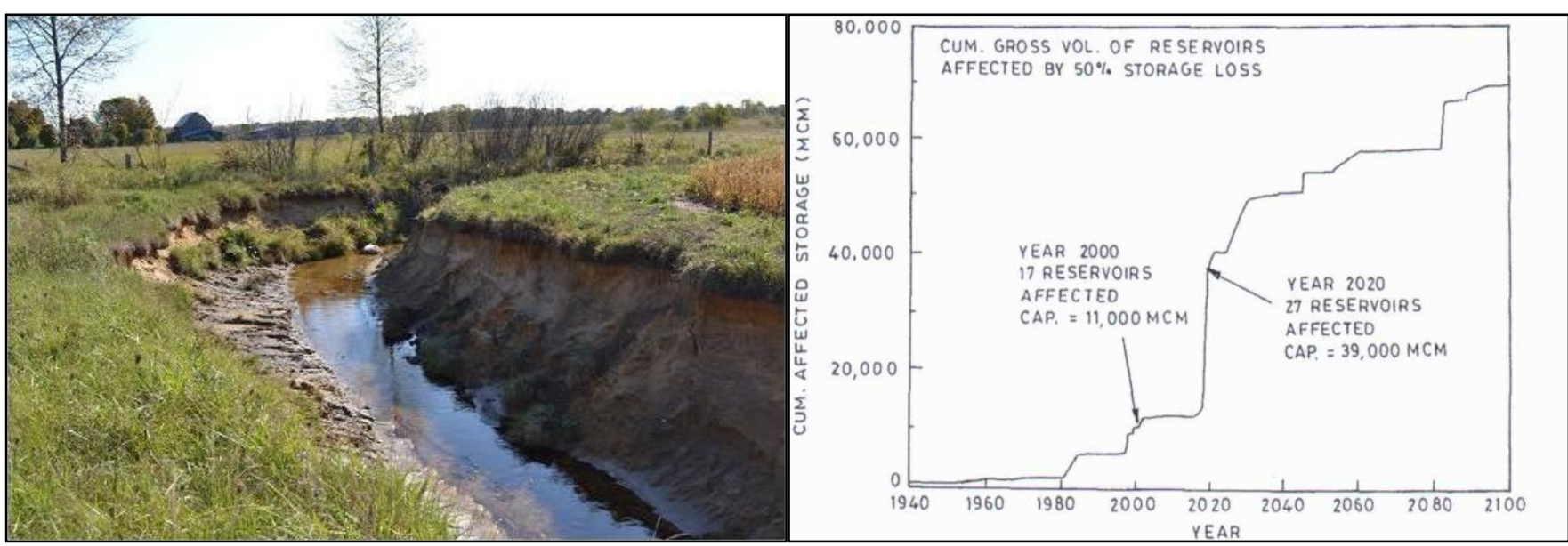

Fig-3: Rate of Sedimentation of Indian Reservoirs

Fig - 4: Bank Erosion 